\title{
sciendo
}

\section{JOB SATISFACTION LEVELS OF MIDWIVES AND FACTORS AFFECTING THOSE LEVELS}

\author{
AYŞE GÜLAY ŞAHAN ${ }^{1}$ \\ ${ }^{I}$ Private YENI NESIL Kindergarten, Altieylul, Balikesir, Turkey
}

Keywords: midwives, job satisfaction level, job satisfaction factors

\begin{abstract}
This study aims to determine the job satisfaction level of midwives, and the factors that have an effect on those levels. This cross-sectional analytic study was carried out in a total of 21 health institutions including 17 primary health care and 4 secondary health care institutions in a city center. 428 midwives were included in the study. To determine the job satisfaction of midwives, the Minnesota Satisfaction Questionnaire (MSQ) was used. According to the scores obtained from MSQ, quartiles in $1 / 4$ were created. In statistical analysis, the difference between the mean scores among groups was analysed with independent samples $t$-test. $P$ values less than 0.05 were considered significant. The results demonstrated that the majority of midwives had a moderate level of job satisfaction.
\end{abstract}

\section{INTRODUCTION}

Healthcare professionals who are qualified are strongly needed for maintaining the health of society. Midwives constitute the most important human power in health services.(1,2) A midwife is defined as an auxiliary healthcare professional who is capable of performing duties related to birth and its processes.(3) Midwives play a key role in public health by protecting maternal and child health, and providing prenatal, delivery and postnatal care.(2) WHO adopts the view that it will not be possible to reach the desired level of public health without the active participation of midwives in health services.(4) There are some factors that affect midwives while fulfilling their expected responsibilities. One of these factors is job satisfaction. Job satisfaction includes the attitude of an employee regarding his/her job, the pleasure he/she takes, and the positive emotional state he/she reaches.(5) The degree of satisfaction of an employee with his job varies according to the degree of pleasure he/she feels or the positive emotional state he/she achieves. $(5,6)$ In this context, midwives with high job satisfaction are expected to provide more efficient and quality service.(7) When studies on job satisfaction of healthcare professionals are examined, it is seen that the number of studies conducted on midwives is limited.(8,9) Increasing the job satisfaction levels of midwives can also increase the quality of midwifery service and the health level of the society. For this purpose, the determination of the job satisfaction levels of midwives and the factors affecting them are considered important.

\section{AIM}

The aim of this study is to determine the job satisfaction levels of midwives and the factors affecting the job satisfaction levels.

\section{MATERIALS AND METHOD}

The data of this cross-sectional analytical study were obtained from 279 midwives who were randomly selected from a total of 428 midwives working in a total of 21 healthcare institutions including 17 primary care and 4 secondary care healthcare institutions in a city center.

The Minnesota Job Satisfaction Scale (Short Form) was used as data collection tool in the study. This scale was developed by Weiss, Dawis, England, and Lofguist (1967) to measure job satisfaction.(10) In this study, the reliability coefficient of the scale was calculated as 0.86 . In the analysis, as the lowest score to be obtained from the study is 35 and the highest score is 100 points, the scores were grouped in $1 / 4$ quartiles, the ones in the highest quartile (84-100 points) were considered as having a "high job satisfaction", the ones in the second (68-83 points) and third quartiles (52-67 points) (50\%) were rated as having "moderate job satisfaction", and the ones in the lowest quartile (35-51 points) were accepted as having "low job satisfaction". The significance of the difference regarding the mean scores of the groups was investigated with the independent samples t-test and the p-values less than 0.05 was considered significant.

\section{RESULTS}

In this section, findings demonstrating the level of job satisfaction and findings in which the mean scores between the groups in terms of independent variables are statistically significant are included.

Table no. 1. Job satisfaction levels of midwives

\begin{tabular}{llll}
\hline $\begin{array}{l}\text { Job Satisfaction Levels } \\
(\mathbf{n = 2 7 9 )}\end{array}$ & Number & $\%$ & $\begin{array}{l}\text { Overall } \\
\text { Mean } \\
\text { Score }\end{array}$ \\
\hline Low & 19 & 6.8 & \\
Moderate & 139 & 49.8 & 68.5 \\
Moderate & 106 & 38 & \\
High & 15 & 5.4 & \\
\hline \multicolumn{4}{c}{ As seen in table no. 1, the findings indicate that the job }
\end{tabular}
satisfaction levels of the majority of midwives were moderate.

${ }^{1}$ Corresponding author: Ayșe Gülay Şahan, Bahçelievler Mah., Çayır Sok., No: 20, Altıeylül, Balıkesir, Turkey. E-mail: gulaysahan2011@ hotmail.com, Phone: +090 2662411727

Article received on 20.01.2021 and accepted for publication on 31.05.2021 


\section{PUBLIC HEALTH AND MANAGEMENT}

Table no. 2. Distribution of midwives' mean job satisfaction levels according to socio-demographic variables

\begin{tabular}{lll}
\hline & $\begin{array}{l}\text { Mean Job } \\
\text { Satisfaction Score } \\
\pm \text { Standard Error }\end{array}$ & $\mathbf{p}^{*}$ \\
\hline $\begin{array}{l}\text { Institution } \\
\text { Primary healthcare institution } \\
(\mathrm{n}=126)\end{array}$ & $70.3 \pm 0.92$ & 0.008 \\
$\begin{array}{l}\text { Secondary healthcare } \\
\text { institution (n=153) }\end{array}$ & $67.0 \pm 0.85$ & \\
\hline $\begin{array}{l}\text { Marital Status } \\
\text { Single, widowed, or divorced } \\
(\mathrm{n}=26)\end{array}$ & $61.2 \pm 1.84$ & 0.000 \\
Married (n=253) & $69.2 \pm 0.65$ & \\
\hline
\end{tabular}

satisfaction scores of midwives working in secondary healthcare institutions were significantly lower than midwives working in primary healthcare institutions. In addition, job satisfaction scores of single, widowed, or divorced midwives were found to be significantly lower than married midwives.

Table no. 3. Distribution of the mean job satisfaction scores of midwives according to the job-related variables

\begin{tabular}{|c|c|c|}
\hline & $\begin{array}{l}\text { Mean Job } \\
\text { Satisfaction Score } \\
\pm \text { Standard Error }\end{array}$ & $\mathbf{p}^{*}$ \\
\hline $\begin{array}{l}\text { Providing midwifery service in } \\
\text { the unit they work }\end{array}$ & & 0.037 \\
\hline Yes $(n=160)$ & $69.6 \pm 0.85$ & \\
\hline No $(n=119)$ & $67.0 \pm 0.92$ & \\
\hline $\begin{array}{l}\text { Using the midwifery knowledge } \\
\text { acquired during undergraduate } \\
\text { education }\end{array}$ & & 0.009 \\
\hline Yes $(n=172)$ & $69.8 \pm 0.80$ & \\
\hline No $(n=107)$ & $66.4 \pm 0.99$ & \\
\hline $\begin{array}{l}\text { Choosing the profession } \\
\text { voluntarily }\end{array}$ & & 0.001 \\
\hline Yes $(n=191)$ & $69.9 \pm 0.73$ & \\
\hline No $(n=88)$ & $65.5 \pm 1.17$ & \\
\hline Weekly working hours & & 0.004 \\
\hline 40 hours $(n=140)$ & $70.3 \pm 0.89$ & \\
\hline 45 hours $(n=139)$ & $66.7 \pm 0.87$ & \\
\hline Working time & & 0.003 \\
\hline $\begin{array}{l}\text { Continuous daytime and night } \\
\text { shift }(n=138)\end{array}$ & $66.6 \pm 0.87$ & \\
\hline Continuous daytime $(n=141)$ & $70.3 \pm 0.89$ & \\
\hline $\begin{array}{l}\text { Total number of workers in the } \\
\text { unit }\end{array}$ & & 0.006 \\
\hline $1-20$ people $(n=214)$ & $69.5 \pm 0.73$ & \\
\hline 21 and more $(n=65)$ & $65.3 \pm 1.14$ & \\
\hline $\begin{array}{l}\text { Threats from patients or their } \\
\text { relatives }\end{array}$ & & 0.000 \\
\hline Yes $(n=124)$ & $65.7 \pm 0.97$ & \\
\hline No $(n=155)$ & $70.7 \pm 0.78$ & \\
\hline $\begin{array}{l}\text { Physical violence from patients or } \\
\text { their relatives }\end{array}$ & & 0.043 \\
\hline Yes $(n=37)$ & $65.2 \pm 1.85$ & \\
\hline No $(n=242)$ & $69.0 \pm 0.66$ & \\
\hline $\begin{array}{l}\text { Threats from healthcare } \\
\text { professionals }\end{array}$ & & 0.000 \\
\hline Yes $(n=34)$ & $61.9 \pm 1.90$ & \\
\hline No $(n=245)$ & $69.4 \pm 0.65$ & \\
\hline
\end{tabular}

Findings in table no. 3 revealed that midwives who did not provide midwifery service in the unit had significantly lower job satisfaction scores compared to those who provided that service. In addition, midwives who did not use their midwifery knowledge in pre-graduation education had lower job satisfaction scores than those who used that information. It was revealed that midwives who did not choose their profession voluntarily had significantly lower job satisfaction scores compared to those who chose voluntarily. In addition, it was found that midwives with more weekly working hours and midwives working daytime and full nightshift had lower job satisfaction levels than midwives with shorter weekly hours and working only in the daytime. Moreover, the midwives working with a large number of staff in the unit had significantly lower job satisfaction scores than those working with fewer people in the unit. Finally, it was found that the job satisfaction scores of midwives who were exposed to threats or violence from healthcare staff or patients and relatives were significantly lower than their colleagues who were not.

\section{DISCUSSIONS
In this study, it was concluded that the job satisfaction} of the majority of midwives was moderate. This result is consistent with the results obtained in studies conducted with Turkish midwives. $(11,12,13)$ In the study conducted by Watson et al. (1999) to find out the job satisfaction of midwives in Australia, it was determined that most of the midwives were satisfied with their jobs.(14) These results are consistent with the results of the study conducted by Cronie et al. (2019) with Dutch midwives.(15) On the other hand, studies have found that the job satisfaction of Iranian and Ethiopian midwives is moderate. $(16,17,18)$ The differences in results can be explained by the fact that the studies were conducted in different countries.

The result that the qualifications of the institution where midwives work have a determining effect on their job satisfaction is consistent with the results obtained in the study conducted by Christopher et al. (1998).(19) The effect of marital status on job satisfaction that was demonstrated in that study is similar to many research results. $(11,18,20)$

Another result of this study is that the weekly working time has a significant effect on the job satisfaction of midwives. In addition, it was found that the total number of workers in the unit is also a determinant of job satisfaction. These results are consistent with several study results in the literature. $(11,15,18,21)$ In the study, it was determined that the job satisfaction scores of the midwives who were not threatened by patients or their relatives were significantly different than those who were. In addition, it was found that the job satisfaction scores of those who did not experience physical violence from patients or their relatives differed significantly from those who experienced physical violence. Finally, it was seen that the mean job satisfaction scores of midwives who were not threatened by healthcare staff were significantly different from those who were. This result is consistent with the results of the research conducted by Sidhu et al. (2020).(22)

\section{CONCLUSIONS}

As a conclusion, it was observed that the majority of midwives have a moderate job satisfaction. The factors affecting job satisfaction levels of midwives were identified as the institution they work for, their marital status, providing midwifery service in the unit they work, using the midwifery knowledge received in pre-graduation education, choosing the profession voluntarily, weekly working hours, working time, total number of staff in the unit, and threats or violence from patients or patients' relatives or healthcare professionals.

\section{Acknowledgment:}

This research was produced from an unpublished master's thesis. I would like to thank my advisor, Prof. Dr. Gazanfer Aksakoğlu, for his contribution to the research.

\section{REFERENCES}

1. WHA. (Translated by G. Telatar) Secretariat Report on Strengthening Nursing and Midwifery 56. World Health Assembly, Temporary Agenda Item. 14.11, A56 / 19. 2003. http://www.un.org.tr/who/WHA/hemsire.htm Adopted 06 


\section{PUBLIC HEALTH AND MANAGEMENT}

June 2019.

2. Öncel S. Midwifery theme of 2001: All women are equal in receiving appropriate health care. Celal Bayar University School of Nursing Journal. 2002;6 (1):24-27.

3. Official Gazette. Regulation on inpatient treatment institutions article 133.05 May 2005. Issue: 25806. https://www.resmigazete.gov.tr/ Adopted 06 June 2020.

4. The legal status of midwifery in Turkey. www.tuspmoe.gen.tr/TR/dosyagoster.aspx?DIL $=1 \&$. Adopted 01 June 2020

5. Eren E. Organizational behavior and management psychology. Extended 8th edition. Istanbul: Beta Publishing; 2004.

6. Şimşek M. Excellence in business life. Ankara: Hayat Publications; 2004.

7. Beech BM. Patient satisfaction and nursing staff work satisfaction in an urban public teaching hospital. Unpublished Doctoral Dissertation, University of Texas. USA, 1995. http://proquest.umi.com. Adopted 29 March 2020.

8. Bodur S. Job satisfaction of health care staff employed at health centers in Turkey. Occupational Medicine. 2002;52 (6):353-355.

9. Hampton GM, Peterson RT. Job satisfaction of certified nurse midwives: an examination. Administrative Issues Journal. 2012;2(2):112-126.

10. Weiss DJ, Dawis RV, England GW, Lofquist LH. Manual for the Minnesota Satisfaction Questionnaire. Minneapolis, MN: University of Minnesota Industrial Relations Center; 1967.

11. Aydin M. Professional satisfaction of midwives working within the municipality of Mersin. Unpublished master's thesis. Mersin: Mersin University; 2007.

12. Gerçek S. The relationship between job satisfaction levels of midwives working in hospitals and health centers and some socio-demographic characteristics. Unpublished master's thesis. Sivas: Cumhuriyet University; 2006.

13. Oflasli F. Determination of job satisfaction levels of midwives working in the field in Denizli province. Unpublished master's thesis. Denizli, Pamukkale University; 2002.

14. Watson L, Potter A, Donohue L. Midwives invictoria Australia: a survey of current issues and job satisfaction. Midwifery. 1999;15(4):216-231.

15. Cronie D, Perdok H, Verhoeven C, Jans S, Hermus M, Vries $\mathrm{RD}$ et al. Are midwives in the Netherlands satisfied with their jobs? A systematic examination of satisfaction levels among hospital and primary-care midwives in the Netherlands. BMC Health Services Research. 2019;19(832):2-10

16. Baqgheri S, Janati A, Kousha A, Sadeghi-Bazargani H, Asghari Jafarabadi M, Farahbaksh M. Job satisfaction differences between primary health care and treatment sectors: an experience from Iran. Health Promotion Perspectives. 2013;3(1):90-101.

17. Khavayet F, Tahery N, Alizadeh Ahvazi M, Tabnak A. A survey of job satisfaction among midwives working in hospitals. Journal of Midwifery and Reproductive Health. 2018;6(1):1186-1192.

18. Bekru ET, Cherie A, Anjulo AA. Job satisfaction and determinant factors among midwives working at health facilities in Addis Ababa city, Ethiopia. Plos One. 2017;12(2):1-16.

19. Christopher J, Morag C, Corinne C. Team midwifery: The views and job satisfaction of midwives. Midwifery. 1998;14(4):214-224.

20. Kim B, Kang SJ. Comparison of professionalism and job satisfaction between Korean midwives in birthing centers and midwives in hospitals. Korean Journal of Women Health Nursing. 2020;26(3):222-230.

21. Sibbald B, Bojke C and Gravelle H. National survey of job satisfaction and retirement intentions among general practitioners in England. BMJ; 2003.

22. Sidhu R, Su B, Shapiro K. R, Stoll K. Prevalence of and factors associated with burnout in midwifery: A scoping review. European Journal of Midwifery. 2020;4(4):1-15. 